\title{
New code of estimating practice
}

Book

Published Version

Flanagan, R. and Jewell, C. (2018) New code of estimating practice. Wiley-Blackwell, Chichester, pp224. ISBN

9781119329466 Available at https://centaur.reading.ac.uk/99400/

It is advisable to refer to the publisher's version if you intend to cite from the work. See Guidance on citing.

Publisher: Wiley-Blackwell

All outputs in CentAUR are protected by Intellectual Property Rights law, including copyright law. Copyright and IPR is retained by the creators or other copyright holders. Terms and conditions for use of this material are defined in the End User Agreement.

\section{www.reading.ac.uk/centaur}

\section{CentAUR}

Central Archive at the University of Reading

Reading's research outputs online 


\section{THE CHARTERED INSTITUTE OF BUILDING}
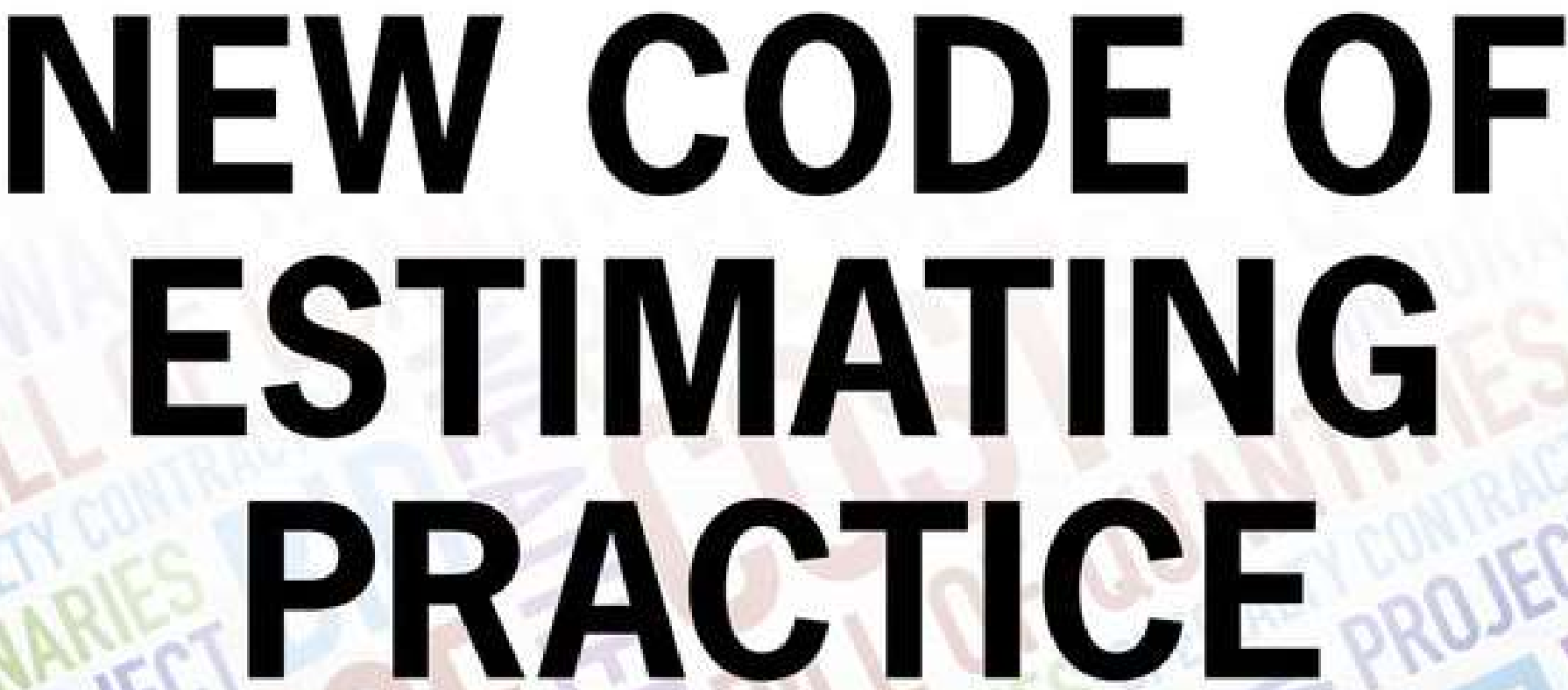

Q R 

New Code of

Estimating Practice 

New Code of

\section{Estimating Practice}

\section{The Chartered Institute of Building}

Roger Flanagan

Carol Jewell

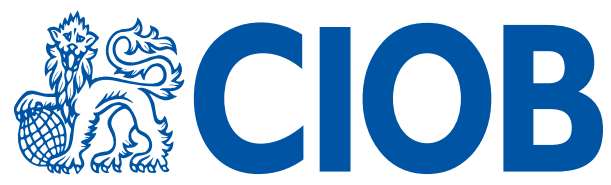

THE CHARTERED INSTITUTE OF BUILDING

WI LEY Blackwell 
This edition first published 2018

(c) 2018 John Wiley \& Sons Ltd

All rights reserved. No part of this publication may be reproduced, stored in a retrieval system, or transmitted, in any form or by any means, electronic, mechanical, photocopying, recording or otherwise, except as permitted by law. Advice on how to obtain permission to reuse material from this title is available at http://www.wiley.com/go/permissions.

The right of The Chartered Institute of Building to be identified as the authors of this work has been asserted in accordance with law.

Registered Offices

John Wiley \& Sons, Inc., 111 River Street, Hoboken, NJ 07030, USA

John Wiley \& Sons Ltd, The Atrium, Southern Gate, Chichester, West Sussex, P019 8SQ, UK

Editorial Office

9600 Garsington Road, Oxford, OX4 2DQ, UK

For details of our global editorial offices, customer services, and more information about Wiley products visit us at www.wiley.com.

Wiley also publishes its books in a variety of electronic formats and by print-on-demand. Some content that appears in standard print versions of this book may not be available in other formats.

Limit of Liability/Disclaimer of Warranty

While the publisher and authors have used their best efforts in preparing this work, they make no representations or warranties with respect to the accuracy or completeness of the contents of this work and specifically disclaim all warranties, including without limitation any implied warranties of merchantability or fitness for a particular purpose. No warranty may be created or extended by sales representatives, written sales materials or promotional statements for this work. The fact that an organization, website, or product is referred to in this work as a citation and/or potential source of further information does not mean that the publisher and authors endorse the information or services the organization, website, or product may provide or recommendations it may make. This work is sold with the understanding that the publisher is not engaged in rendering professional services. The advice and strategies contained herein may not be suitable for your situation. You should consult with a specialist where appropriate. Further, readers should be aware that websites listed in this work may have changed or disappeared between when this work was written and when it is read. Neither the publisher nor authors shall be liable for any loss of profit or any other commercial damages, including but not limited to special, incidental, consequential, or other damages.

Library of Congress Cataloging-in-Publication Data applied for

Paperback ISBN: 9781119329466

Cover design by Wiley

Cover image: $\odot$ Zephyr18/Gettyimages

Set in 10/13pt ITCFranklinGothic by SPi Global, Chennai, India

$\begin{array}{llllllllll}10 & 9 & 8 & 7 & 6 & 5 & 4 & 3 & 2 & 1\end{array}$ 


\section{Contents}

Foreword

Glossary xiii

Code of estimating and tendering practice - principles and procedures $\quad x x V$

Section One Principles - the theory and background 1

1 Introduction 3

1.1 An imprecise science 3

1.2 Data, information, and knowledge in estimating 4

1.3 Experience, instinct, gut feel, intuition and bias 5

1.4 Optimism bias 6

2 The Fundamentals $\quad 7$

2.1 Tender and bid $\quad 7$

$\begin{array}{lll}2.2 & \text { Pricing } & 7\end{array}$

2.3 Profitability 8

2.4 Types of tender 9

$\begin{array}{lll}2.5 & \text { Tender award } & 10\end{array}$

2.6 The difference between procurement and tendering 10

2.7 Methods of procurement 11

$3 \quad$ Changes driving estimating practice 13

$\begin{array}{lll}3.1 & \text { Digitisation } & 13\end{array}$

3.2 E-Tendering 14

3.3 Legislation and taxation 14

$\begin{array}{lll}3.4 & \text { Bureaucracy } & 14\end{array}$

3.5 Competition and winning work 14

$\begin{array}{lll}3.6 & \text { Specialisation } & 15\end{array}$

3.7 New technologies and off-site production 15

3.8 New methods of procurement 15

$\begin{array}{lll}3.9 & \text { Best value } & 15\end{array}$ 
$\begin{array}{lll}4 & \text { The bid process } & 17\end{array}$

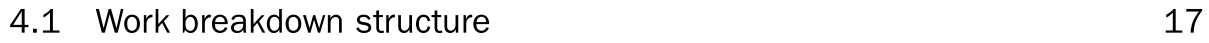

$\begin{array}{lll}4.2 & \text { Underlying principles } & 18\end{array}$

$5 \quad$ Health and safety $\quad 25$

5.1 Introduction $\quad 25$

5.2 Estimating the cost of health and safety 25

$6 \quad$ The pre-qualification process $\quad 31$

6.1 Introduction $\quad 31$

6.2 Bidding for public sector projects 32

7 Procurement, selection, contractual arrangements and legal issues $\quad 37$

$\begin{array}{lll}7.1 & \text { Methods of procurement } & 37\end{array}$

7.2 Two-stage tendering 43

$\begin{array}{lll}7.3 & \text { Framework agreements } & 44\end{array}$

7.4 Concession contracts $\quad 44$

7.5 Engineer Procure Construct (EPC) 46

7.6 Prime contracting 46

7.7 Early contractor involvement (ECI) $\quad 47$

7.8 Integrated Project Delivery (IPD) 47

$\begin{array}{lll}7.9 & \text { Selection processes } & 47\end{array}$

7.10 Integrated design and construction $\quad 49$

$\begin{array}{ll}7.11 \text { E-procurement } & 49\end{array}$

$\begin{array}{ll}7.12 \text { E-auctions } & 50\end{array}$

$\begin{array}{ll}7.13 \text { Abnormally low tenders } & 50\end{array}$

8 Preliminaries $\quad 51$

8.1 Site establishment 51

8.2 Insurances, bonds and so on 58

$\begin{array}{lll}8.3 & \text { Site records } & 61\end{array}$

$\begin{array}{lll}8.4 & \text { Fees and charges } & 62\end{array}$

8.5 Compliance 63

8.6 Environmental management 65

8.7 Wastewater treatment system 68

$\begin{array}{lll}8.8 & \text { Waste management } & 69\end{array}$ 
$\begin{array}{ll}\text { 8.9 Waste disposal, sorting and storage } & 71\end{array}$

8.10 Setting out $\quad 74$

8.11 Control and protection $\quad 75$

8.12 Completion and post-completion requirements 76

$\begin{array}{ll}8.13 \text { Contingencies } & 77\end{array}$

$\begin{array}{ll}\text { 8.14 Management and staff } & 78\end{array}$

$9 \quad$ Temporary Works $\quad 81$

9.1 Introduction $\quad 81$

9.2 Temporary works management 83

9.3 Temporary works co-ordinator (TWC) 83

9.4 Temporary works supervisor $\quad 84$

9.5 Temporary works register $\quad 84$

9.6 Temporary works design brief 84

9.7 Scaffolding $\quad 89$

$\begin{array}{lll}9.8 & \text { Falsework } & 92\end{array}$

9.9 Formwork 93

9.10 Earthworks 94

$\begin{array}{ll}9.11 \text { Temporary services } & 97\end{array}$

9.12 Façade retention 98

9.13 Structures - design and loading 99

$\begin{array}{ll}9.14 \text { Plant foundations } & 100\end{array}$

$\begin{array}{ll}9.15 \text { Protection on-site } & 100\end{array}$

$\begin{array}{ll}9.16 \text { Traffic management } & 101\end{array}$

9.17 Temporary access for vehicles and pedestrians 101

9.18 Barriers for pedestrians and vehicles 101

$\begin{array}{ll}9.19 \text { Haul roads } & 102\end{array}$

9.20 Works associated with any ordnance uncovered 102

$\begin{array}{ll}9.21 \text { Signage } & 102\end{array}$

$\begin{array}{ll}9.22 \text { Protection of adjacent properties } & 102\end{array}$

10 Cost-estimating techniques 103

$\begin{array}{ll}10.1 \text { Approximate quantities } & 108\end{array}$

$\begin{array}{ll}10.2 \text { Cost planning } & 110\end{array}$ 
11 Private finance initiative/public-private partnerships/build, operate and transfer, and whole-life costing

12 Risk management

12.1 Background

12.2 Risk analysis

12.3 Cost estimating accuracy

13.1 Materials logistics plan

13.2 Materials management

13.3 Personnel management and health and safety

13.4 Plant, tools and equipment - maintenance and management

13.5 Transportation

13.6 Traffic management

\section{Resource and production planning}

14.1 Planning techniques

14.2 Resource planning

14.3 Time - its perception and impact on the estimating process

16 BIM and the estimating process

16.1 Overview

16.2 The challenges of using BIM in the estimating process

\section{Section Two Processes - the practice}

1.1 Receive preliminary enquiry

1.2 Consider order backlog/new orders

1.3 Decision to tender (bid or no bid)

1.4 Project information, schedule and questionnaire

1.5 Consider client and consultant team and project delivery availability 149

1.6 Assessment criteria - lowest price/quality and so on

1.7 The likely competition 
2.4 Examine documents - contract, design, bonds, warranties and insurance

2.5 Site visit - utilities, ground conditions, adjacent properties and so on

2.6 Method statement/logistics plan

3.1 Special employer requirements and modifications to standard clauses

4.1 Pricing the works

4.2 Establish unit rates - labour and plant

178

4.3 Establish unit rates - labour, materials and plant

180

4.4 Labour cost issues - a summary 185

4.5 Build-up unit rates 186

4.6 Gang sizes for activities 189

4.7 Allocation of costs 192

4.8 All-in rates for plant and equipment 194

4.9 Select materials and specialty contractors' quotations 197

4.10 Specialty contractor quotations 199

4.11 Provisional sums - defined and undefined 200

4.12 Incorporating provisional sums in an estimate 200

4.13 Daywork 204

4.14 Pricing the preliminaries 205

4.15 Add allowances

206

$5 \quad$ Prepare estimator's report

211

6 Examine and consider

215

6.1 Examine preliminaries $\quad 216$

6.2 Requests for further information $\quad 216$

6.3 Examine method and tender programme 216

$\begin{array}{lll}6.4 & \text { Examine resource costs } & 217\end{array}$

6.5 Consider the competition for the project in the market 217

6.6 Consider cash flow and capital requirements for the project 217

$7 \quad$ Bid assembly and adjudication $\quad 219$

$\begin{array}{lll}7.1 & \text { Finalise the pricing } & 220\end{array}$

$\begin{array}{ll}7.2 \text { Bid adjudication/final review } & 221\end{array}$

7.3 Qualification of any special items of tender 222 